Journal of Humanities, Social and Management Sciences (JHSMS)

eISSN: 2788-4791 (online)

https://doi.org/10.47264/idea.jhsms/2.2.16

Vol. 2, No. 2 (July-December 2021), 213-227

https://www.ideapublishers.org/index.php/jhsms

Research Article

\title{
Religion, community resilience and countering violent extremism in Dir Valley, Pakistan
}

\author{
Shakeel Ahmed ${ }^{1} \mid$ Imran Ahmad Sajid $^{* 1}$ | Beenish Ijaz Butt ${ }^{2}$ \\ 1. Department of Social Work, University of Peshawar, Peshawar, Pakistan. \\ 2. Department of Social Work, University of Sargodha, Sargodha, Pakistan. \\ *Corresponding Author Email: imranahmad131@uop.edu.pk
}

Received: September 12, 2021

Published: December 15, 2021

\begin{abstract}
The post 9/11 terrorism and subsequent wave of violent extremism has generated a significant interest in the role of religion in both peace and conflict. Religion is a significant part of the lives of a significant majority the global population. This realization has led policy makers to seek ways in which religious leaders can and had impacted the community resilience towards violent extremism. Swat and Dir valleys have seen the brunt of violent extremism in the recent past. This extremism was generated and exploited by a few religiously motivated violent organizations. However, we believe there were religious leaders who opposed this surge of violent extremism in those specific communities. This research aims at finding out whether religious leaders mobilized the communities for countering violent extremism. In order to do that, a quantitative survey was designed whereby a community perception was measured. The data was collected from 180 respondents from both the districts of Dir valley, i.e., lower Dir and upper Dir. Our data shows that religious leaders played some role in building community resilience. In terms of bonding, they played a significant role. In terms of bridging, they also played a significant role. However, in terms of linking, the religious leaders played a little role.
\end{abstract}

Keywords: TTP, TNSM, CVE, Dir Valley, Swat, community, community engagement, religious leaders, violent extremism, community resilience, radicalisation.

\section{How to Cite:}

Ahmed, S., Sajid, I. A., \& Butt, B. I. (2021). Religion, community resilience and countering violent extremism in Dir Valley, Pakistan. Journal of Humanities, Social and Management Sciences (JHSMS), 2(2), 213-227. https://doi.org/10.47264/idea.jhsms/2.2.16

Publisher's Note: IDEA PUBLISHERS (IDEA Publications Group) stands neutral regarding jurisdictional claims in the published maps and institutional affiliations.

Copyright: @ 2021 The Author(s), published by IDEA PUBLISHERS (IDEA Publications Group).

Licensing: This is an Open Access article published under the Creative Commons AttributionNonCommercial 4.0 International License (http://creativecommons.org/licenses/by-nc/4.0/) 


\section{Introduction}

The post 9/11 terrorism and subsequent wave of violent extremism has generated a significant interest in the role of religion in both peace and conflict. Religion is a significant part of the lives of around $84 \%$ of the global population (PEW Research Centre, 2017). This realization has led policy makers to seek ways in which religious leaders can and had impacted the community resilience towards violent extremism (Mandaville, 2017).

This research looks at the role of religious leaders in countering violent extremism in Dir valley. The year 2008 saw a surge in violent extremist activities in Malakand division of the Khyber Pakhtunkhwa province which includes district Swat, Dir Lower, Dir Upper, Chitral, Shangla and Buner. The major area of operation for the extremist elements was Swat from where they also tried to expand their sphere of influence to adjacent valleys including Dir. However, Dir strongly resisted the extremist elements through many measures including building 'local peace committees' (Ahmad et al., 2013; Rehman, 2013; Azim et al., 2018). This research believes that religious leaders played an effective role in mobilizing the communities towards countering this wave of violent extremism in Dir Valley.

This research is important in many ways. Although the National Action Plan, a counterterrorism plan of Pakistan, suggests measures for countering religious persecution, registration of religious seminaries, strict actions against sectarianism, etc (NACTA, 2014). But it seems to have missed on engaging religious leaders in building community resilience in countering violent extremism. This research fills this gap in the counter-terrorism policy of Pakistan by indicating the role of religious leaders not only in instigating violent extremism but also countering as well. This is needed because religious leaders are an important part of civil society with deep roots within communities. Engaging religious leaders for building community resilience towards countering violent extremism is a viable option.

\subsection{Background of the problem}

In the post 9/11 world, Khyber Pakhtunkhwa has faced the most severe threats of violent extremism. The Malakand division in particular saw a violent secession and expansionist movement by the Tehrik-e-Taliban Pakistan (TTP). The frequent attacks on law-enforcing agencies, the beheading of civilians and armed personals, hate speech against the state of Pakistan, its agencies and constitution, and frequent threats to the public in Swat lead to a military operation called Operation Rah-e-Nijat and Operation Rah-e-Rast in 2008-09. This led the entire population of Swat to move out of their houses to other districts (Khan, 2020). Since TTP was a religiously motivated organization, therefore there is a general tendency to see religion and violent extremism to have a positive association by Pakistani researchers. Nonetheless, not all religious leaders joined TTP and spread violent extremism. Some stood against them and mobilized the local communities to counter TTPs narrative and other actions (Aslam et al., 2020). These efforts, however, are either missing in Pakistani literature on religion and violent extremism or discussed inadequately.

\subsection{Objectives and research questions}

The major objective of this research study is to explore the community perception towards the role of religious leaders in countering violent extremism in Dir Valley. This goal is achieved 
through two objectives: (a) to find out whether religious leaders have mobilized the communities for countering violent extremism through Friday sermons and (b) to find out whether religious leaders have mobilized the communities for countering violent extremism through other means. The entire research revolves around the research question as: What was the role of religious leaders in building the community resilience towards countering violent extremism in Dir valley?

\section{Literature review}

Literature on Countering Violent Extremism (CVE) suggests significant role of education, and women, religion. Inclusion of the concept of community resilience (CR) to CVE is relatively new. In this literature review, we briefly discuss education, women and CVE. We then move on to a substantial review of literature on community resilience (CR) to CVE. Further, a detailed literature review is also presented with respect to religious leaders and CVE. This section finally discusses about Pakistan and CVE. Here, the literature review found that the concept of CR to CVE has yet to gain ground in Pakistan. Furthermore, the review suggests that although the role of religious leaders in CVE has been researched in Pakistan to a great extent, nonetheless, the role of religious leaders in building CR for CVE has not been researched as of now.

\subsection{Community resilience and CVE}

No doubt, our knowledge of what works in countering violent extremism is still limited (Gielen, 2019). Gielen suggest that what works question should be discarded in favour of a more realist 'what works, for whom, in what circumstances, and how' question. Many researchers have focused on community-based approaches towards countering violent extremism and have come up with favourable findings (see for example Dalgaard-Nielsen, 2016; Ellis \& Abdi, 2016; Wasai et al., 2020).

Social control theory of crime presented by Hirschi (1969) asserts that strong bonds to family, community and society are essential to prevention of violence. Building on this theory, Ellis and Abdi (2016) assert that social connection is at the heart of building community resilience. They introduce two key concepts to counter violent extremism: social connection and social linking. Social connection is the boding and bridging between community members. This, they assert, can diminish risk for violent extremism. Social linking is the connection between community and government agencies. The partnership of government agencies with communities can lead to early intervention for violent extremism and in the process strengthens community resilience towards violent extremism.

The model presented by Ellis and Abdi (2016) identifies three types of social connection that are significant in countering the violent extremism vis-a-vis boding, bridging and linking. Each of these connections can mitigate the risk factors to the violent extremism within and between the communities. Bonding is connection, a sense of belonging, between individuals who are similar in significant ways. This connection creates identities amongst individuals. Strong connections create strong identity, e.g., ethnic identity. Weak connections can lead to an identity crisis amongst community members. The concept of bonding is significant for this research as the concept leads us to ask questions whether religious leaders perform any role in bonding of communities in Dir valley of Khyber Pakhtunkhwa? A more fundamental question 
could be whether religious leaders can perform any function in building identities within communities? The answer, to many researchers, is affirmative (See for example King, 2003; Miller \& Anderson, 2009; Yip et al., 2010).

Bridging is connection between those who are dissimilar in significant ways. This difference could be based on ethnicity, social class, or religion. Bridging are connections between individuals or groups with diverse social identities. Weak bridging may lead to social marginalization or lack of attachment to national identity. We are interested in finding out whether religious leaders perform any role in bridging of communities in Dir Valley? Furthermore, what role is performed by religious leaders in bridging communities? A brief look into the literature suggests a significant role of religious leaders in bridging communities (See for example Allen, 2010; Brady, 2019).

Lastly, linking, as mentioned earlier, is connection and partnership with government agencies. Weak linking with government agencies may lead to lack of public trust between government agencies and the communities per se. Many researchers assert engaging religious leaders by government agencies and civil society for CVE (Mandaville \& Nozell,2017; Omar, 2016). In this research, we are interested in knowing whether religious leaders performed any linking role with government agencies.

Ellis and Abdi (2016) present CBPR (Community based Participatory Research) model to strengthen community resilience towards violent extremism. Their study suggests that CBPR is effective approach in overcoming stigma, cultural barriers, and building trusting relationships. They warn against an overemphasis on one particular group vulnerable to violent extremist ideology (e.g., Muslims). This, they assert, leads to stigma and discrimination which in turn weakens bridging and linking, the very pillars of community resilience.

Salyk-Virk (2018) identified some of the 'tensions' between government CVE programs and the communities where they were implemented.

Box 2.1: Religious Leaders \& building Community Resilience

- Bonding: Creating a sense of peaceful Muslim identity

- Bridging: Creating a sense of Muslim Ummah/Brotherhood

- Linking: Cooperating with government agencies, LEA etc

Source: Ellis and Abdi (2016)

The Box 2.1 summarizes the concept of community resilience and how it may be applied by religious leaders.

\subsection{Religious leaders and CVE}

The USIP Special Report 413 recognizes potential role that religious leader can play in peace and in conflict. Before discussing the role of religious leaders in CVE, the report thoroughly discusses religion and religious leaders as potential drivers of violent extremism (Mandaville \& Nozell, 2017). Nonetheless, the report asserts that "High levels of religious devotion or observance are poor predictors of support for or participation in violent extremism". The report concludes that 'right-sizing' of the role of religion and religious actors in CVE ought to be the focus of CVE policy. 
In his doctoral research focused on role of religious leaders in CVE in Kenya, Hassan (2017) reported that religious leaders took several measures in CVE in two of the research focused counties of Kenya. These include advocacy, education and training, convening dialogue, mediation, reconciliation, and making forums with government agencies. However, the most significant measure taken by religious leaders to CVE was education and training followed by advocacy and reconciliation (for further details see, Gul et al., 2020; Qurban et al., 2020).

The research of Hassan (2017) also reports on effectiveness of religious leaders in CVE. He measured effectiveness in terms of enhanced cultural identity, peacebuilding, community cohesion, restoration, and intra-cultural interactions. He reported that the religious leaders were found to be significantly effective in the peacebuilding and community cohesion. Nonetheless, they were moderately effective in enhancing the cultural identity, restoration, and/or the intracultural interactions.

Amongst the many challenges faced by religious leaders, the most significant is the lack of trust and cooperation from the state-apparatus. In some communities of Mombasa, Kenya, many Imams (religious leaders) were asked to identify suspicious activities in terms of violent extremism. When they did so, they lost trust and credibility of the very communities they served. They were considered as government agents (Mandaville \& Nozell, 2017). Neither the state apparatus trusted them nor the communities. The state apparatus even considered them as part of the problem and not solution. Religious leaders, reported Hassan (2017), often receive death threats from both the government agencies and terrorist groups. Therefore, he recommends assurance of protection from government agencies to religious leaders.

Although comprehensive in many ways, the dissertation of Hassan (2017) does not include the concept of community resilience and how religious leaders may enhance community resilience to CVE. This leaves room for the present research.

Box 2.2: Measures by religious leaders for countering violent extremism

- Advocacy

- Education and Training

- Convening Dialogue

- Mediation

- Reconciliation

- Forums with Government Agents

Source: Hassan (2017).

The Box 2.2 summarizes the role of religious leaders in CVE in Kenya. This may be used as a basis for exploring the role of religious leaders in CVE in Dir valley (upper and lower Dir), Khyber Pakhtunkhwa, Pakistan.

\subsection{Pakistan and CVE}

Basit (2015) suggested that the policy to Countering Violent Extremism (CVE) ought to focus on "individual-focused de-radicalization" and "environment-focused counter-radicalization strategies". He asserts that increasing religiosity may not be the right indicator to measure violent extremism in Pakistani context. He criticizes the religious based analysis of violent extremism in Pakistan and considers them 'flawed' and 'misleading' to counter violent 
extremism. He also suggests understanding of religious, ethnic, and identity dynamics of violent extremism in Pakistan. Criticizing the current de-radicalization focused policy of the state, he considers community approach, a combination of state and society response, "to resist the appeal of militant ideologies".

Religion is the recurring theme in almost all major discourses of VE in Pakistan. Sial (2013) asserts the need of religious scholars, mainly Muslims, to counter radicalization and VE. Identifying the ideological confusion over radicalization and terrorism, Sial presents findings from PIPS survey to assert importance of religion and religious scholars in the society. He highly recommends exposure of religious scholars to observe and understand state systems (for details see, Khan et al. 2020). Although Sial (2013) provided many good recommendations from state and civil society perspectives to religious scholars, his paper misses to mention how religious scholars can build community resilience towards CVE.

This review found that a significant research effort is dedicated to the religious leaders and CVE while little attention has been paid in building community resilience to CVE. Furthermore, this review also highlighted that in Pakistan, the concept of CR to CVE has rarely, if any, been researched.

\section{Research methodology}

This paper is based on a quantitative survey whereby community perception was measured using Likert scale questionnaire.

\subsection{Locale of the study}

The data for the study was collected from two districts of the Dir valley: lower Dir and upper Dir. The research team visited Timergara (the centre of Lower Dir) and Dir Khas (centre of Upper Dir).

\subsection{Nature of respondent and sampling}

Anyone whose minimum age was 30 and who was the resident of Dir valley was considered a potential research participant. This was influenced by the fact that the episode of violent extremism occurred in Dir valley during $2^{\text {nd }}$ half of the $1^{\text {st }}$ decade of $21^{\text {st }}$ Century. We needed someone who was adult enough at that time (at least 18 years of age or above). Therefore, anyone with the age 30 and above was the criterion for inclusion of research participant. The respondents were divided into the nine (09) categories including schoolteachers, shopkeepers, university teachers, hospital staff, labourer's, politicians, transporters (drivers/conductors), NGO workers, and religious leaders (imams). A total of 90 respondents from each district (180 in total) participated in this study. The reason this categorization was made was to diversify the nature of respondents. These categories represent people from almost all walk of life of the Dir valley (upper and lower Dir). This gave a perspective from almost all walks of life respondents to this research.

\subsection{Tool of data collection}

In this research, the major instrument for data collection was questionnaire while interview and 
focused group discussions also perform minor function in data collection. Since measuring the concept of CVE and CR requires quantification of responses, therefore this research utilizes a questionnaire, which is the most suitable tool to measure a concept. Needless to say, here that the questionnaire was based in parts on works of Ellis and Abdi (2016) and Hassan (2017) as illustrated in conceptual framework in Box 3.1 above. It is pertinent to mention here that the questionnaire was also converted in Urdu language. Overall role of religious leaders to CVE was measured through a 04 items scale. Concept of 'bonding' was measured through 04 items scale while 'bridging' and 'linking' were measured through 03 items scale respectively. Measures to CVE were measured through 05 items scale while effects of taking measures to CVE were measured through a 04 items scale.

\subsection{Reliability of research tool}

In order to find out how reliable our research tool was, we conducted a reliability test (Cronbach's Alpha) through SPSS on a sample of 40 respondents from both the districts. As Table-1 shows, the Cronbach's Alpha score was 0.947 which means a high internal consistency and reliability of the research tool.

Table-1: Reliability statistics

\begin{tabular}{lll}
\hline Cronbach's Alpha & $\begin{array}{l}\text { Cronbach's Alpha Based on } \\
\text { Standardized Items }\end{array}$ & N of Items \\
\hline 0.947 & 0.945 & 25 \\
\hline
\end{tabular}

\subsection{Data analysis technique}

The collected data was put into SPSS v.16 software. Thereby, it was analysed through univariate tables. A bi-variate analysis was also carried out on some of the variables to investigate variations. The analysis was guided by the conceptual framework given in the Box 2.1 above.

\section{Results and discussion}

As stated previously, this study involves univariate and bi-variate analysis of the collected data. We further conducted mean score analysis where we felt necessary. Besides mean score analysis, histogram analyses were also conducted.

\subsection{Quantitative analysis}

\subsubsection{How significantly VE affected the respondents?}

Table- 2 shows where the respondents were personally affected by violent extremism and how significantly. As per the data, 44.4\% $(\mathrm{N}=80)$ of the respondent were significantly affected by violent extremism while $8.9 \%(\mathrm{~N}=16)$ said they were very significantly affected by violent extremism. On the other hand, $30 \%$ of the respondents $(\mathrm{N}=54)$ said they were affected but a little bit. Only $13.3 \%(\mathrm{~N}=24)$ said they were personally not affected by violent extremism. Overall, the data shows that majority of the respondents were significantly affected by violent extremism in Dir valley. 


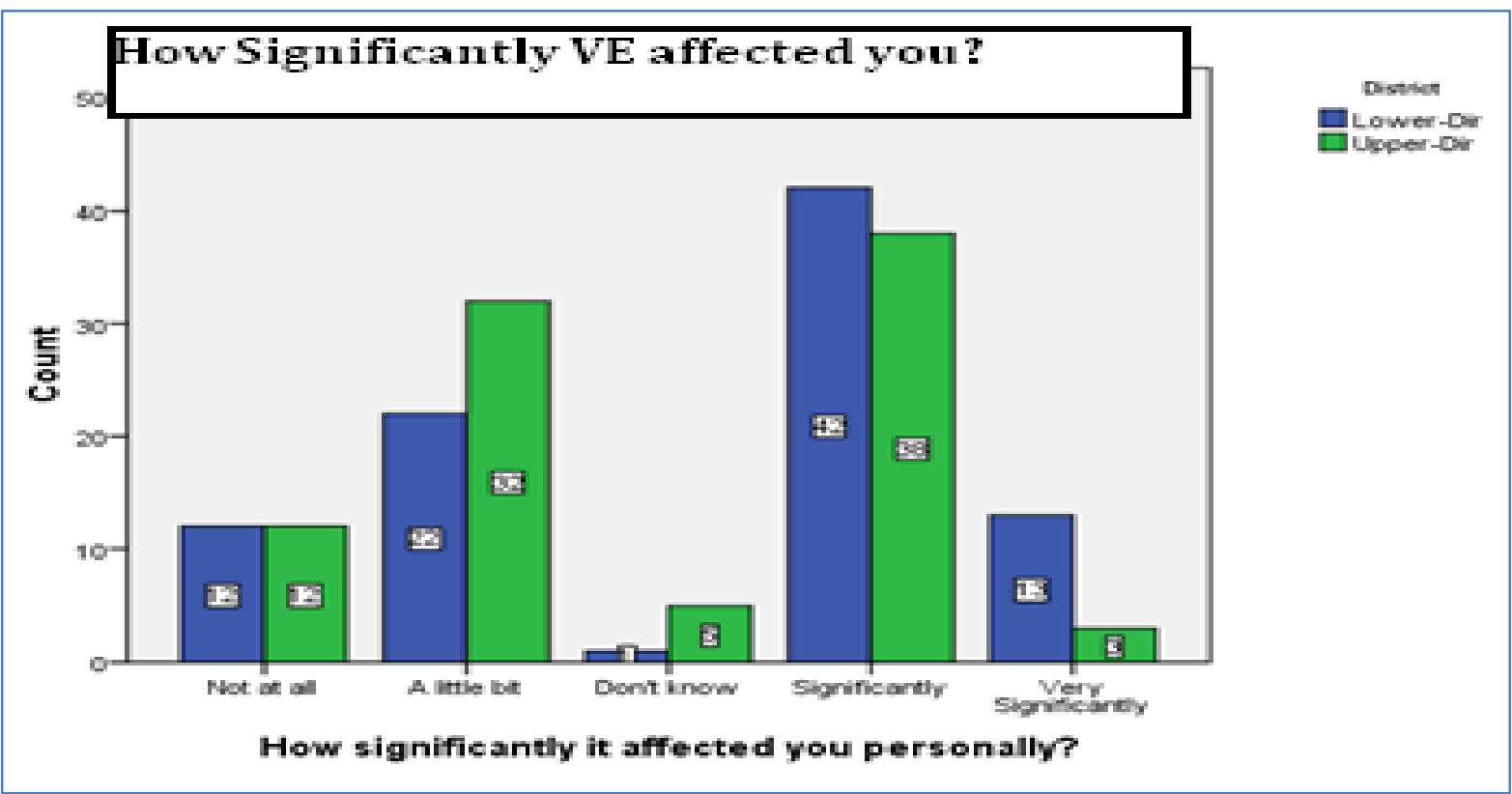

Compared to Upper Dir, respondents from Lower Dir were more significantly affected where $81 \%(\mathrm{~N}=13 / 16)$ from Lower Dir said they were very significantly affected by violent extremism. Looking at the graph, all the bars of Lower Dir on significant side are higher.

The reason why Lower Dir was more significantly affected lies in the geography of the district. Lower Dir is directly sharing active borders, borders that are frequently used by residents from both sides for economic and social activities, with Swat valley. However, the borders of Upper Dir are not active. Hence, the wave of VE spread from Swat to Lower Dir and gradually started to move on to Upper Dir. However, the impact was lower in Upper Dir owing to geography.

Table-2: How significantly VE affected you?

\begin{tabular}{|c|c|c|c|c|c|}
\hline & & & \multicolumn{2}{|c|}{ District } & \multirow{2}{*}{ Total } \\
\hline & & & Lower-Dir & Upper-Dir & \\
\hline \multirow{10}{*}{$\begin{array}{l}\text { How significantly it affected } \\
\text { you personally? }\end{array}$} & \multirow{2}{*}{ Not at all } & Count & 12 & 12 & 24 \\
\hline & & \%age & $50.0 \%$ & $50.0 \%$ & $100.0 \%$ \\
\hline & \multirow{2}{*}{ A little bit } & Count & 22 & 32 & 54 \\
\hline & & \%age & $40.7 \%$ & $59.3 \%$ & $100.0 \%$ \\
\hline & \multirow{2}{*}{ Don't know } & Count & 1 & 5 & 6 \\
\hline & & \%age & $16.7 \%$ & $83.3 \%$ & $100.0 \%$ \\
\hline & \multirow{2}{*}{ Significantly } & Count & 42 & 38 & 80 \\
\hline & & \%age & $52.5 \%$ & $47.5 \%$ & $100.0 \%$ \\
\hline & \multirow{2}{*}{ Very Significantly } & Count & 13 & 3 & 16 \\
\hline & & \%age & $81.2 \%$ & $18.8 \%$ & $100.0 \%$ \\
\hline \multirow{2}{*}{ Total } & & Count & 90 & 90 & 180 \\
\hline & & $\%$ age & $50.0 \%$ & $50.0 \%$ & $100.0 \%$ \\
\hline
\end{tabular}

* District Crosstabulation 


\subsubsection{Role of religious leaders in building community resilience towards CVE}

Table-3 shows the mean score for role of religious leaders in countering violent extremism in Dir valley. On scale of 1 to 5 , there were four items in variable. The table shows an overall somewhat positive role of religious leaders in countering violent extremism in Dir valley with a mean score of 13.36 and standard deviation of 4.67. The histogram shows that the bell is skewed slightly to the right, i.e., to the more positive side of the graph. Therefore, we cannot negate the role of religious leaders in countering violent extremism in Dir valley.

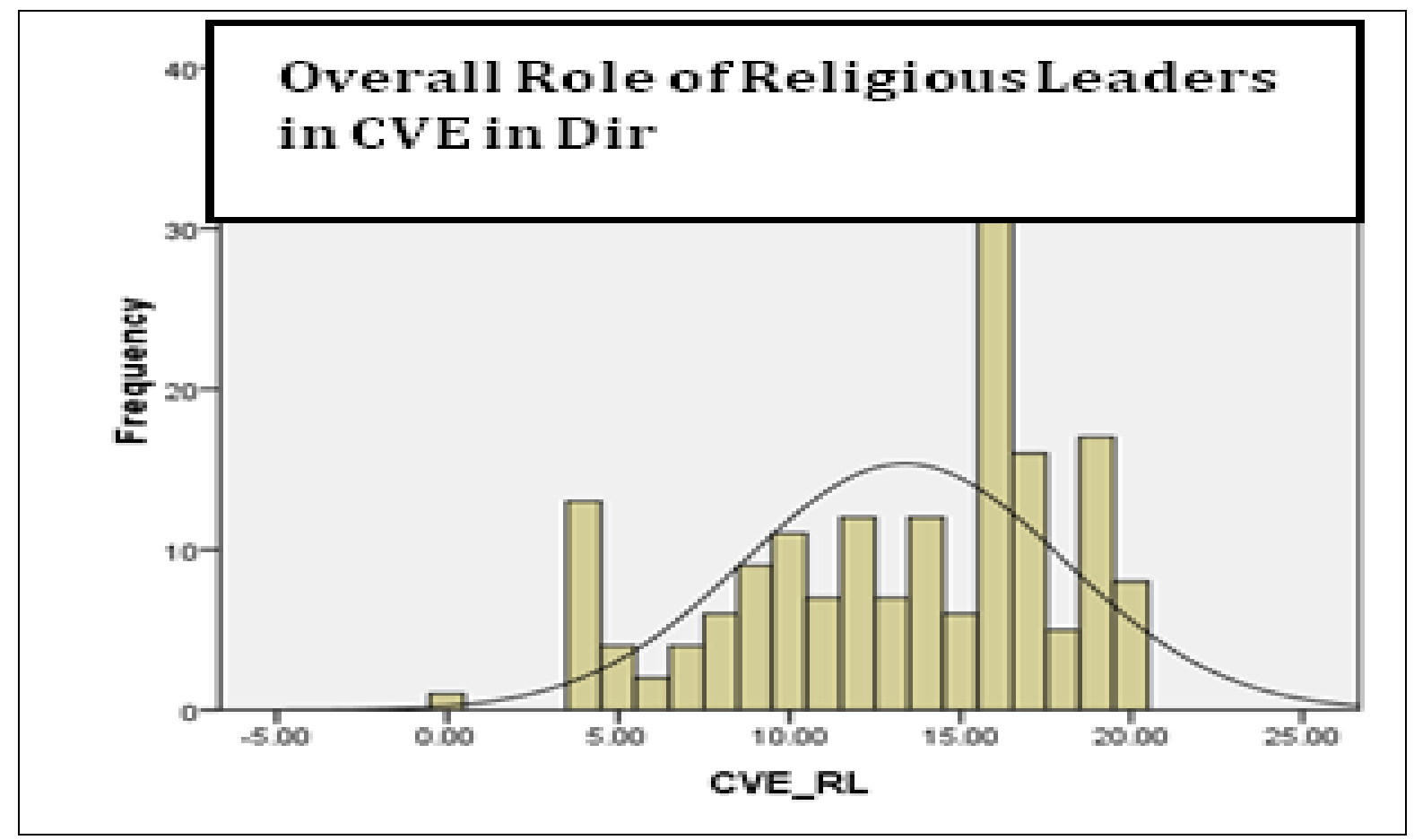

Before this study, a CVE study focusing on religious leaders in Dir valley was non-existent. Nonetheless, the data from the responses of the residents of Dir valley indicates a slightly positive role of the religious leaders in CVE.

Table-3: Overall role of religious leaders in CVE in Dir

\section{Statistics}

CVE_RL

\begin{tabular}{lll}
\hline $\mathrm{N}$ & Valid & 180 \\
& Missing & 0 \\
Mean & & 13.3667 \\
Std. Deviation & & 4.67359 \\
\hline \hline
\end{tabular}

Table-4 and the associated Graphs $(7.1,7.2,7.3)$ shows the role of religious leaders in building community resilience in countering violent extremism. As stated previously, there are three major variables of community resilience towards countering violent extremism vis bonding, bridging, and linking. Bonding was measured through 04 items while Bridging and Linking were measured through 3 items scales respectively. 
Religion, community resilience and countering violent extremism in Dir Valley, Pakistan

Table-4: Role of religious leaders in building community resilience towards CVE



Table-4 shows the mean score for bonding was 12.74 with Standard Deviation of 4.29 (out of total 16). This means religious leaders had a significant role in creating bonding amongst people of Dir. A look at graph 'bonding' shows that the bell is more skewed to the right, i.e., indicator for a positive role.

In terms of Bridging, the mean score was 9.47 with Standard Deviation 3.10 (out of maximum 15). This again shows a significant role of religious leaders in bridging the communities. Looking at the graph 'bridging' shows that the bell is slightly skewed to the right.

In terms of Linking, nonetheless, the mean score is lower at 9.27 with Standard Deviation of 3.57. This means that in terms of linking the communities to the state or other institutions, the religious leader did not perform very well. Looking at graph 'linking' shows that the bell is almost at the centre.

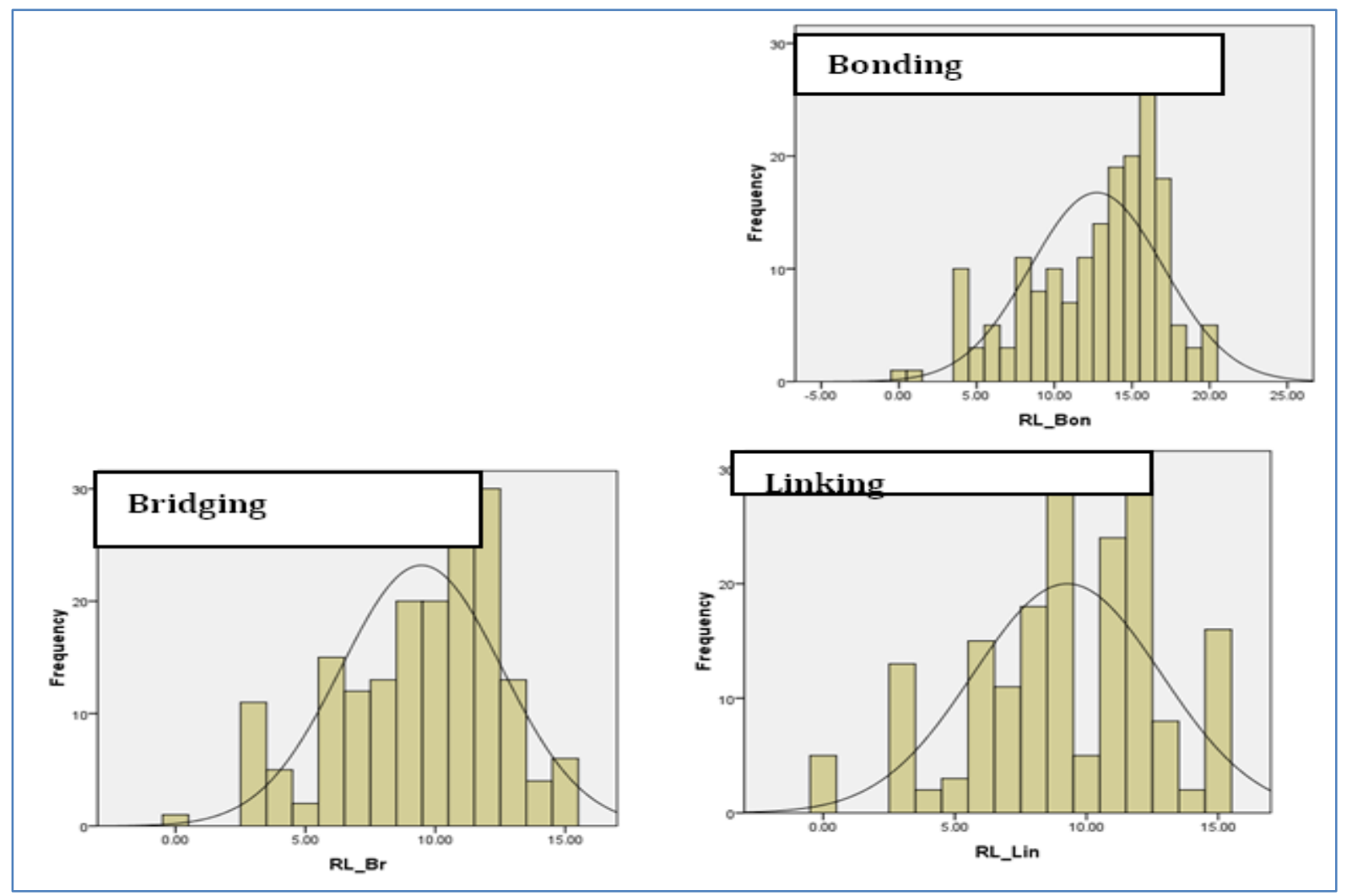

It can be inferred from this data that religious leaders performed well to build CR through bonding and bridging, which are related to community and common folks. However, linking, 
that involves connection with government agencies at different levels, seemed quite lower showing a poor involvement by state agencies of religious leaders for CVE.

\subsubsection{Measures to CVE by religious leaders}

Table- 5 shows different measures taken by religious leaders to counter violent extremism. At least five major measures were identified in the literature and used in this study. In terms of advocacy against VE, there was a mix response from the respondents. The data isn't significantly skewed to either side. However, $33.33 \%(n=60)$ respondents agreed while $10.56 \%$ $(n=19)$ strongly agreed that the religious leaders did conduct advocacy against violent extremism. Nonetheless, a significant majority of the respondents, $28.33 \%(n=51)$ was unsure whether religious leaders advocated against VE.

Similarly, in terms of educating the community members (Muqtadis) against VE, the data shows that the religious leaders performed somewhat positive role as $33.33 \%(n=60)$ agreed and $10.56 \%(\mathrm{n}=19)$ strongly agreed that the religious leaders in their communities educated their followers/community members against VE.

Table-5: Measures to CVE by RL

\begin{tabular}{|c|c|c|c|c|c|c|c|c|c|}
\hline Measures & $\begin{array}{c}\text { Freq. / } \\
\% \text { age }\end{array}$ & 1 & 2 & 3 & 4 & 5 & Total & Missing & Total \\
\hline \multirow{2}{*}{$\begin{array}{l}\text { Advocacy against } \\
\text { VE }\end{array}$} & $\mathrm{F}$ & 25.00 & 24.00 & 51.00 & 60.00 & 19.00 & 179.00 & 1.00 & 180 \\
\hline & $\%$ age & 13.89 & 13.33 & 28.33 & 33.33 & 10.56 & 99.44 & 0.56 & 100 \\
\hline \multirow{2}{*}{$\begin{array}{l}\text { Education of } \\
\text { community } \\
\text { members (Muqtadi) } \\
\text { to CVE }\end{array}$} & $\mathrm{F}$ & 20.00 & 20.00 & 51.00 & 60.00 & 28.00 & 179.00 & 1.00 & 180 \\
\hline & \%age & 11.11 & 11.11 & 28.33 & 33.33 & 15.56 & 99.44 & 0.56 & 100 \\
\hline \multirow{2}{*}{$\begin{array}{l}\text { Convening } \\
\text { dialogues to CVE }\end{array}$} & $\mathrm{F}$ & 28.00 & 27.00 & 79.00 & 35.00 & 10.00 & 179.00 & 1.00 & 180 \\
\hline & \%age & 15.56 & 15.00 & 43.89 & 19.44 & 5.56 & 99.44 & 0.56 & 100 \\
\hline \multirow{2}{*}{$\begin{array}{l}\text { Mediation to } \\
\text { resolve disputes of } \\
\text { community } \\
\text { members }\end{array}$} & $\mathrm{F}$ & 22.00 & 23.00 & 37.00 & 73.00 & 24.00 & 179.00 & 1.00 & 180 \\
\hline & \%age & 12.22 & 12.78 & 20.56 & 40.56 & 13.33 & 99.44 & 0.56 & 100 \\
\hline \multirow{2}{*}{$\begin{array}{l}\text { Engaged at } \\
\text { different forums of } \\
\text { government }\end{array}$} & $F$ & 20.00 & 23.00 & 53.00 & 51.00 & 32.00 & 179.00 & 1.00 & 180 \\
\hline & $\%$ age & 11.11 & 12.78 & 29.44 & 28.33 & 17.78 & 99.44 & 0.56 & 100 \\
\hline
\end{tabular}

In terms of convening dialogues to counter VE, the role of religious leaders seems to be insignificant as majority of the respondents, $444 \%(n=79)$ said that they don't know if any such dialogue was convened by their religious leaders.

A more significant role was performed by the religious leaders in terms of mediating to resolve disputes amongst community members as $40.56 \%(n=73)$ agreed to the statement while $13.33 \%$ $(n=24)$ strongly agreed that the religious leaders in their communities performed positive role in mediating to resolve disputes of the community members.

Finally, whether religious leaders were engaged at different forums also received mixed responses. Overall, 29\% $(n=53)$ respondents said that they don't know of any such 
engagements of their religious leaders. Nonetheless, $28 \%(\mathrm{n}=51)$ and $18 \%(\mathrm{n}=32)$, agreed and strongly agreed to a significant role of religious leaders in engagements at different forums.

\subsubsection{Effects of measures taken by religious leaders to CVE}

Table- 6 shows whether the measures taken by the religious leaders to counter violent extremism had any effect. This variable was measured through four (04) items scale. It shows an overall mean score of 11.83 with st.d. 4 . This means their measures had a slightly positive effect on countering violent extremism.

Table-6: Overall effects of measures to CVE by RL

\section{Statistics}

RL_E_Mes

\begin{tabular}{lll}
\hline $\mathrm{N}$ & Valid & 179 \\
& Missing & 1 \\
Mean & & 11.83 \\
Std. Deviation & & 4.00 \\
\hline \hline
\end{tabular}

Table-7 shows itemized effects of measures taken by religious leaders to counter violent extremism. It shows that they contributed significantly in enhancing local identity (row (a) $35 \%, \mathrm{n}=63$ and $7.78 \%, \mathrm{n}=14$ ). Further, religious leaders also contributed significantly in enhancing Muslim identity amongst community members (row b, 36.67\%, $\mathrm{n}=66$ and $23.33 \%$, n-42). Furthermore, religious leaders also enhanced social cohesion amongst community members (row c, $35.56 \%, \mathrm{n}=64$ and $13 \%, \mathrm{n}=23$ ).

However, measures taken by religious leaders to counter violent extremism also generated some mistrust in the community members against the religious leaders.

Table-7: Itemized effects of measures to CVE

\begin{tabular}{|c|c|c|c|c|c|c|c|c|c|}
\hline Effects & f/ & 1 & 2 & 3 & 4 & 5 & Total & Missing & Total \\
\hline \multirow{2}{*}{$\begin{array}{l}\text { Enhancing Dirwal } \\
\text { Identity }\end{array}$} & $\mathrm{f}$ & 39.00 & 19.00 & 44.00 & 63.00 & 14.00 & 179.00 & 1.00 & 180 \\
\hline & $\%$ & 21.67 & 10.56 & 24.44 & 35.00 & 7.78 & 99.44 & 0.56 & 100 \\
\hline \multirow{2}{*}{$\begin{array}{l}\text { Enhancing Muslim } \\
\text { Identity }\end{array}$} & $\mathrm{f}$ & 26.00 & 14.00 & 31.00 & 66.00 & 42.00 & 179.00 & 1.00 & 180 \\
\hline & $\%$ & 14.44 & 7.78 & 17.22 & 36.67 & 23.33 & 99.44 & 0.56 & 100 \\
\hline \multirow{2}{*}{$\begin{array}{l}\text { Enhancing } \\
\text { Community cohesion }\end{array}$} & $\mathrm{f}$ & 27.00 & 22.00 & 43.00 & 64.00 & 23.00 & 179.00 & 1.00 & 180 \\
\hline & $\%$ & 15.00 & 12.22 & 23.89 & 35.56 & 12.78 & 99.44 & 0.56 & 100 \\
\hline \multirow{2}{*}{$\begin{array}{l}\text { Mistrust of } \\
\text { community members }\end{array}$} & $\mathrm{f}$ & 53.00 & 32.00 & 49.00 & 32.00 & 13.00 & 179.00 & 1.00 & 180 \\
\hline & $\%$ & 29.44 & 17.78 & 27.22 & 17.78 & 7.22 & 99.44 & 0.56 & 100 \\
\hline
\end{tabular}

\section{Conclusion}

As Box 2.1 of conceptual framework shows that the major data revolved around religious leaders and their role in building community resilience, which was measured through three 
variables vis bonding, bridging, and linking. Our data shows that religious leaders played some role in building community resilience. In terms of bonding, they played a significant role. In terms of bridging, they also played a significant role. However, in terms of linking, the religious leaders played a little role.

Box 2.2 of conceptual framework also shows what measures were taken by religious leaders to counter violent extremism. Such measures were measured through a five variables scale vis advocacy, education, dialogue, mediation, and engagement with government (Table-5). The data showed that religious leaders did perform well in terms of advocacy against VE (Table5). In terms of educating the community members against VE, the data also shows that the religious leaders performed well (Table-5). However, the data shows little role of religious leaders in convening dialogues (Table-5). A more significant role was performed by religious leader in mediating the disputes amongst community members (Table-5). Nonetheless, the data shows that there was very little engagement of religious leaders at different forums of the government (Table-5).

The case study of Dir Valley regarding role of religious leaders in CVE shows us quite pleasing results. Since our data shows a very low level of engagement of religious leaders by state agencie $3 \mathrm{~s}$, this study recommends more engagement of religious leaders by state agencies for CVE. This could be achieved by arranging various training programs and projects for religious leaders in CVE. De-radicalization projects and CVE projects should be directed towards more engagement of religious leaders in CVE.

\section{References}

Ahmad, N., Asad, A., Farhatullah, Shah, S. (2013). Local peace committees: Potentials contributing factors in the peace-building process in conflict-affected areas of Pakistan. Pakistan Journal of Criminology, 5(2), 103-114. http://www.pjcriminology.com/wp-content/uploads/2019/01/7-14.pdf

Allen, R. (2010). The bonding and bridging role of religious institutions for refugees in a nongateway context. Ethnic and Racial Studies, 33(6), 1049-68. https://doi.org/10.1080/01419870903118130

Aslam, T., Rizvi, S. M. A. S., \& Aslam, M. A. (2020). Counter-terrorism: Push and pull factors impacting male youth involved in violent extremism in Punjab, Pakistan. Liberal Arts and Social Sciences International Journal (LASSIJ), 4(1), 303-316. https://doi.org/10.47264/idea.lassij/2.1.5

Azim, S. W., Mehmood, W., \& Hussain, S. (2018). Swat Conflict in Retrospect: Violence and Jarga among the Swat Pukhtuns in Pakistan. Liberal Arts and Social Sciences $\begin{array}{llll}\text { International Journal } & \text { (LASSIJ), } & 2(1), & 37-48 .\end{array}$ https://doi.org/10.47264/idea.lassij/2.1.5

Basit, A. (2015). Countering violent extremism: Evaluating Pakistan's counter-radicalization and de-radicalization initiatives. IPRI Journal, 15(2), 44-68. https://www.ipripak.org/wp-content/uploads/2015/10/3-art-s-15.pdf

Brady, A. (2019). Working with religious leaders for peaceful and cohesive societies. Tony Blair Institute for Global Change. https://institute.global/policy/working-religiousleaders-peaceful-and-cohesive-societies 
Dalgaard-Nielsen, A. (2016). Community resilience to militant Islamism: Who and what? An explorative study of resilience in three Danish communities. Democracy and Security, 12(4), 309-27. https://doi.org/10.1080/17419166.2016.1236691

Ellis, B. H., \& Abdi, S. (2016). Building community resilience to violent extremism through genuine partnerships. American Psychologist, 72(3), 289-300. https://psycnet.apa.org/doi/10.1037/amp0000065

Gielen, A. J. (2019). Countering violent extremism: A realist review for assessing what works, for whom, in what circumstances, and how? Terrorism and Political Violence, 31(6), 1149-1167. https://doi.org/10.1080/09546553.2017.1313736

Gul, A., Bashir, T., \& Mustafa, J. (2020). Role of Educational Institutions in Building a Peaceful Society. Liberal Arts and Social Sciences International Journal (LASSIJ), 4(2), 267-277. https://doi.org/10.47264/idea.lassij/4.2.21

Hassan, M. A. (2017). The role of religious leaders in countering violent extremism in Mandera and Mombasa Counties. Institute of Diplomacy and International Studies, University of Nairobi.

Hirschi, T. (1969). Causes of delinquency. University of California.

Khan, S. (2020). Community perception toward post operation Rah-e-Rast rehabilitation of Temporary Displaced Persons of Swat. Unpublished MS Thesis, Institute of Peace and Conflict Studies, University of Peshawar.

Khan, Z., Ullah, R., \& Kamal, U. (2020). Pathways of Youth Radicalization in Pashtun Society: Applying the Anomie and Strain Theory. Liberal Arts and Social Sciences International Journal (LASSIJ), $3(2), \quad 150-157$. https://doi.org/10.47264/idea.lassij/3.2.17

King, P.E. (2003). Religion and identity: The role of ideological, social, and spiritual contexts. Applied Developmental Science, $\quad 7(3), \quad$ 197-204. https://doi.org/10.1207/S1532480XADS0703_11

Mandaville, P. (2017). Engaging religion and religious actors in countering violent extremism. USIP Special Report 413. https://www.usip.org/sites/default/files/SR413-EngagingReligion-and-Religious-Actors-in-Countering-Violent-Extremism.pdf

Mandaville, P. G., \& Nozell, M. (2017). Engaging religion and religious actors in countering violent extremism (p. 8). United States Institute of Peace. https://www.usip.org/sites/default/files/SR413-Engaging-Religion-and-ReligiousActors-in-Countering-Violent-Extremism.pdf

Miller, L., and Anderson, G. L. (2009). Religion's role in creating national unity [With Comment and Rejoinder]. International Journal on World Peace, 26(1), 91-138. https://www.jstor.org/stable/20752875

NACTA. (2014). National Action Plan. In Government of Pakistan, National Counter Terrorism Authority, Islamabad. https://nacta.gov.pk/nap-2014/

Omar, M. (2016). Partnering up: How to work with religious leaders to counter violent extremism. World Policy Journal,33(4), 73-79. https://jliflc.com/wpcontent/uploads/2017/01/Omar_Partnering-up-how-to-work-with-religious-leadersto-CVE.pdf

PEW Research Center. (2017, April 15). The changing global religious landscape. https://www.pewforum.org/2017/04/05/the-changing-global-religious-landscape/

Qurban, S., Amin, H., \& Siddiqa, M. (2020). Discourse of Pakistan's Identity under Strand of Liberal Citizenship: A Case Study of Musharraf Education Policy Reforms. Liberal Arts and Social Sciences International Journal (LASSIJ), 4(1), 189-202. https://doi.org/10.47264/idea.lassij/4.1.17 
Rehman, Z. (2013, December 27). Taliban coming to Dir. Friday Times. https://www.thefridaytimes.com/taliban-coming-to-dir/

Salyk-Virk, M. J. (2020). Building community resilience? Community perspectives of the countering violent extremism pilot program in Minneapolis/St. Paul. Studies in Conflict \& Terrorism, 43(11), 10111042.https://doi.org/10.1080/1057610X.2018.1514054

Sial, S. (2013). Role of religious scholars in counter-radicalization and deradicalization strategies in Pakistan: The need and the scope. Conflict and Peace Studies, 5(1), 6984.

Wasai, Ullah, J., \& Bano, A. (2020). Militancy and Pashtun Culture: Challenges and Developments in Pashtun Society in Khyber Pakhtunkhwa, Pakistan. Liberal Arts and Social Sciences International Journal (LASSIJ), 3(2), 115-127. https://doi.org/10.47264/idea.lassij/3.2.14

Yip, J., Twohill, E., Ernst, C., \& Munusamy, V. P. (2010). Leadership in faith-based nonprofits: The power of identity boundaries to bind and blind. Nonprofit Management and Leadership, 20(4), 461-472. https://doi.org/10.1002/nml.20005 